\title{
Respon Pertumbuhan dan Hasil Tanaman Cabe Rawit terhadap Pemberian Beberapa Dosis Kotoran Ayam di Tanah Podsolik Merah Kuning
}

\section{Growth and Yield Response of Cayenne Pepper to Giving Some Manure Chicken Dosage in Red Yellow Podsolic Soils}

\author{
Fahrudin $^{1)}$ \& Mahdiannoor ${ }^{2)}$ \\ Program Studi Agroteknologi, Sekolah Tinggi Ilmu Pertanian Amuntai \\ 1)fhrn@gmail.com \\ ${ }^{2)}$ mahdi_186@yahoo.com
}

\begin{abstract}
ABSTRAK
Cabe rawit atau lombok merupakan tanaman sayuran buah yang diperlukan oleh seluruh lapisan masyarakat sebagai penyedap masakan dan obat-obatan. Pada umumnya tanaman cabe rawit dapat tumbuh di segala jenis tanah dan berkembang dengan baik bila syarat-syarat tumbuhnya terpenuhi, akan tetapi yang paling baik adalah di dataran rendah pada tanah yang mengandung pasir dengan porositas baik. Penelitian ini bertujuan untuk (i) mengetahui respon pertumbuhan dan hasil cabe rawit terhadap pemberian beberapa dosis pupuk kandang kotoran ayam dan (ii) mendapatkan dosis kotoran ayam terbaik terhadap pertumbuhan dan hasil cabe rawit di tanah podsolik merah kuning. Percobaan ini dilaksanakan di Desa Timbun Tulang Kecamatan Batu Mandi Kabupaten Balangan dari bulan Juni - September 2010, menggunakan Rancangan Acak Kelompok (RAK) faktor tunggal, dengan ulangan 4 kali dan kombinasi satuan percobaan 7 buah, dengan demikian untuk keseluruhan percobaan sebanyak 28 petak percobaan. Hasil penelitian menunjukkan bahwa perlakuan dosis pupuk kandang kotoran ayam berpengaruh nyata pada tinggi tanaman umur 14 HST, berpengaruh sangat nyata pada tinggi tanaman umur 21 dan 28 HST, umur tanaman mulai berbunga dan berat basah tanaman cabe rawit. Perlakuan terbaik untuk pertumbuhan tinggi tanaman umur 14, 21 dan 28 HST; umur mulai berbunga dan bobot buah segar pertanaman cabe rawit adalah perlakuan $k_{5}(1,4 \mathrm{~kg}$ pupuk kandang kotoran ayam/lubang tanam).
\end{abstract}

Kata kunci : Cabe, rawit, dosis, kotoran, ayam.

\section{ABSTRACT}

Cayenne pepper or chilli is a fruit vegetable crops needed by the whole society as a flavoring food and medicine. In general, chilli plants can be grown in all types of soil and grow best when growing conditions are met, but the best is in the lowland soil containing sand with good porosity. This study aimed to know (i) the growth and yield response of cayenne pepper extending of multiple doses of the chicken manure fertilizer (ii) the best doses of chicken manure fertilizer on the growth and yield chili in red yellow podzolic soil. The experiment was conducted in the Timbun Tulang Village Batu Mandi District Balangan Regency from June - September 2010, using a randomized block design (RBD) a single factor, with repeated 4 times and the combination of experimental units 7 pieces, so for the entire experiment were 28 experimental plots. The results showed that treatment doses of chicken manure droppings significant effect on plant height age 14 day after planting (DAP), significant effect on plant height ages 21 and 28 DAP, age of the plant starts to flower and plant fresh weight chili. The best treatment for high-growth plant ages 14,21 and 28 DAP, age starts to flower and fruit fresh weight chili crop is treated $k_{5}$ (1.4 kg chicken manure fertilizer / planting hole).

Keywords: Chili, cayenne, dosage, dung, chicken.

\section{PENDAHULUAN}

Peningkatan produksi sayuransayuran adalah penting, karena disamping sangat berguna dalam perbaikan nilai gizi, juga sangat penting peranannya dalam pembangunan pertanian, khususnya tanaman hortikultura.

Cabe rawit merupakan tanaman sayuran buah yang diperlukan oleh seluruh lapisan masyarakat sebagai penyedap masakan dan obat-obatan. Cabe rawit lebih sering dikenal sebagai sayuran rempah atau 
bumbu dapur banyak mengandung gizi yang masing-masing jenisnya berlainan, terutama banyak mengandung vitamin $\mathrm{A}, \mathrm{B}$, dan $\mathrm{C}$ serta mineral $\mathrm{Ca}, \mathrm{Fe}, \mathrm{P}$, dan air (Sunaryono, 2003).

Kebutuhan pasar yang cukup meningkat dan harga jual yang cukup tinggi, merupakan salah satu motivasi yang dapat mendorong para petani cabe rawit untuk dapat lebih mengembangkan usaha taninya. Pengembangan budidaya cabe rawit khususnya di Kalimantan Selatan masih kurang disukai. Kendala utama yang dihadapi dalam pembudidayaan tanaman cabe rawit yaitu bahwa lahan pertanian yang sebagian besar didominasi oleh tanah marginal, sehingga masih terbatas penggunaannya untuk pertanian, terutama tanah podsolik yang diketahui mempunyai sifat fisik, kimia, dan biologi yang tidak menguntungkan bagi pertumbuhan tanaman.

Kalimantan Selatan mempunyai luas areal lahan kering sekitar 2.759.838 ha dan sebagian besar didominasi jenis tanah podsolik merah kuning lebih kurang 1.203.445 ha. Lahan kering ini mempunyai potensi untuk dikembangkan menjadi daerah pertanian (Dinas Pertanian Kalimantan Selatan, 1996).

Menurut Departemen Pertanian (2006), tingkat produksi dan kualitas cabe rawit di Kalimantan Selatan khususnya Kabupaten Balangan masih sangat rendah, yaitu pada tahun 2006 jumlah produksi hanya 3,76 ton/ha. Sedangkan pada tahun 2007 terdapat peningkatan jumlah produksi menjadi 3,89 ton/ha. Walaupun demikian kebutuhan cabe rawit masih kurang untuk dikonsumsi dan sebagian kekurangannya didatangkan dari daerah Kalimantan Timur. Rendahnya produksi tanaman cabe rawit di wilayah ini disebabkan karena sebagian besar tanahnya terdiri dari tanah podsolik. Munir (1996), dimana tanah podsolik ini terbentuk dari bahan induk lempung berpasir sehingga kurang mampu untuk menahan unsur hara atau mengikat unsur hara, sehingga tanaman mengalami hambatan dalam perkembangannya.

Berdasarkan hasil uji laboratorium sampel tanah pada lokasi penelitian (Lab. Kimia, Fisika dan Biologi Tanah Faperta
Unlam, 2010) adalah kandungan C 6,29 \% kriteria sangat tinggi, $\mathrm{N} 0,26 \%$ kriteria sedang, $\mathrm{K}_{2} \mathrm{O} 6,06 \mathrm{mg} / 100 \mathrm{~g}$ kriteria sangat rendah, $\mathrm{P}_{2} \mathrm{O} 5$ total $8,27 \mathrm{mg} / 100 \mathrm{~g}$ kriteria sangat rendah, $\mathrm{P}_{2} \mathrm{O} 5$-Bray 1,22 ppm kriteria sangat rendah, Fe-larut 267,45 ppm kriteria sangat tinggi, $\mathrm{pH} \mathrm{H}_{2} \mathrm{O} 3,75$ kriteria sangat masam, pH KCL 3,20 kriteria sangat masam, DHL/salinitas $0,09 \mathrm{mS} / \mathrm{cm}$ kriteria sangat rendah, Ca-dd 7,50 me/100 gr kriteria tinggi, Mg-dd 0,50 me/100 gr kriteria rendah, Na-dd $0,18 \mathrm{me} / 100$ gr sangat rendah, K-dd 0,20 me/100 gr kriteria rendah, KTK 23,98 me/100 gr kriteria tinggi, Al-dd 2,94 me/100 gr kriteria rendah, dan H-dd 1,11 me/100 gr kriteria sangat rendah.

Tanah podsolik merah kuning umumnya mempunyai sifat tingkat kesuburan yang rendah, bereaksi masam, sangat miskin unsur hara N, P, K dan Ca serta kelarutan $\mathrm{Al}, \mathrm{Fe}$ dan $\mathrm{Mn}$ yang sangat tinggi sehingga menyebabkan fiksasi $\mathrm{P}$ dan keracunan tanaman di samping itu juga kandungan bahan organiknya tergolong rendah sampai sangat rendah. Kondisi ini menyebabkan rata-rata produksi tanaman cabe rawit masih tergolong rendah.

Tanah podsolik merah kuning dilihat dari sifat fisik dan kimia merupakan tanah yang miskin unsur hara sehingga diperlukan suatu usaha untuk memperbaiki kondisi tanah tersebut. Perbaikan tanah podsolik merah kuning biasa dilakukan dengan pemberian pupuk, baik pupuk organik maupun pupuk anorganik. Salah satu pupuk organik yang digunakan adalah pupuk kandang kotoran ayam.

Pemberian pupuk ke dalam tanah, baik yang bersumber dari pupuk organik maupun anorganik merupakan suatu usaha untuk meningkatkan produksi tanaman. Salah satu faktor yang membatasi produksi tanaman adalah kurangnya tersedianya unsur hara dalam media tumbuh tanaman. Pemupukan merupakan upaya untuk mencapai kebutuhan unsur hara bagi perkembangan tanaman yang dapat meningkatkan produktivitas tanah dan produksi tanaman. Dengan pemberian pupuk pada tanaman diusahakan tercapai keseimbangan hara bagi pertumbuhan tanaman sehingga dapat dicapai produksi 
yang optimal (Sutedjo dan Kartasapoetra, 1991).

Pupuk kandang kotoran ayam merupakan pupuk organik yang berasal dari kandang ternak berupa kotoran padat bercampur sisa makanan dan kotoran cair (urine) sekaligus, pemberian pupuk kandang kotoran ayam mampu memberikan unsur hara bagi tanaman. Kelebihan pupuk kandang kotoran ayam jika dibandingkan dengan jenis kotoran lainya adalah kandungan unsur $\mathrm{N}$ yang cukup tinggi sehingga mampu menunjang pada fase vegetatif tanaman khususnya untuk pertumbuhan batang, kandungan unsur $\mathrm{N}$ juga sangat berperan dalam pembentukan protein dan asam nukleat yang dipakai untuk pengisian inti sel yang terus membelah diri satu menjadi dua dan seterusnya sehingga tanaman dapat tumbuh dan membesar (Sutedjo, 1995).

Tujuan Penelitian ini adalah (i) untuk mengetahui respon pertumbuhan dan hasil cabe rawit terhadap pemberian beberapa dosis pupuk kandang kotoran ayam di tanah podsolik merah kuning, dan (ii) untuk mengetahui dosis kotoran ayam terbaik yang memberikan respon pertumbuhan dan hasil cabe rawit di tanah podsolik merah kuning.

\section{METODE PENELITIAN}

Penelitian ini dilaksanakan di Desa Timbun Tulang, Kecamatan Batu Mandi, Kabupaten Balangan, Provinsi Kalimantan Selatan. Penelitian dilaksanakan selama \pm 4 bulan, yaitu dimulai pada tanggal 15 Juni 15 September 2010.

Bahan dan alat yang digunakan adalah media, pupuk kandang kotoran ayam, air, pestisida dan polybag kecil. Alat - alat yang digunakan adalah cangkul, parang, ember, hand sprayer, gergaji, palu, timbangan, meteran, kamera dan alat tulis.

Penelitian ini merupakan percobaan yang dilakukan di lapangan dengan menggunakan Rancangan Acak Kelompok (RAK) faktor tunggal, yaitu perlakuan pupuk kandangan kotoran ayam. Faktor yang dicobakan berupa perlakuan pupuk kandang kotoran ayam sebanyak 7 taraf, yaitu : $\mathrm{k}_{0}=0$ $\mathrm{kg}$ (tanpa pupuk kandang kotoran ayam), $\mathrm{k}_{1}$ $=0,3 \mathrm{~kg}$ pupuk kandang kotoran ayam/lubang tanam, $\mathrm{k}_{2}=0,5 \mathrm{~kg}$ pupuk kandang kotoran ayam/lubang tanam, $\mathrm{k}_{3}=$ 0,9 kg pupuk kandang kotoran ayam/lubang tanam, $\mathrm{k}_{4}=1,1 \mathrm{~kg}$ pupuk kandang kotoran ayam/lubang tanam, $\mathrm{k}_{5}=1,4 \mathrm{~kg}$ pupuk kandang kotoran ayam/lubang tanam, $\mathrm{k}_{6}=$ $1,7 \mathrm{~kg}$ pupuk kandang kotoran ayam/lubang tanam. Perlakuan yang dicobakan diulang sebanyak 4 kali. Pengelompokan berdasarkan tinggi bibit tanaman cabe rawit. Dengan demikian untuk keseluruhan percobaan sebanyak 28 petak percobaan.

Pelaksanaan percobaan meliputi penyemaian benih, pengolahan tanah, penanaman pemupukan, pemeliharaan, pemanenan. Pengamatan yang dilaksanakan pada percobaan ini adalah pengukuran tinggi tanaman $(\mathrm{cm})$, umur berbunga (hari), bobot buah segar per tanaman (g). Untuk mengetahui ada tidaknya pengaruh beberapa tingkat dosis pupuk kandang kotoran ayam terhadap variabel yang diamati maka dilakukan analisis ragam dengan menggunakan uji $\mathrm{F}$ pada taraf uji $1 \%$ dan 5 $\%$, tetapi sebelum dilakukan analisis ragam, terlebih dahulu data diuji dengan uji kehomogenan ragam Bartlett pada taraf $1 \%$. Bila hasil uji $F$ berbeda nyata atau sangat nyata maka dilakukan uji DMRT pada taraf uji $5 \%$.

\section{HASIL DAN PEMBAHASAN}

Hasil
Tinggi Tanaman
Berdasarkan hasil analisis ragam,
pemberian beberapa dosis pupuk kandang
kotoran ayam berpengaruh nyata terhadap
rata- rata tinggi tanaman cabe rawit umur 14
HST dan berpengaruh sangat nyata terhadap
rata- rata tinggi tanaman cabe rawit umur 21
dan 28 HST. Hasil uji beda nilai tengah
pemberian beberapa dosis pupuk kandang
kotoran ayam terhadap rata - rata tinggi
tanaman cabe rawit umur 14, 21 dan 28 HST
dapat dilihat pada Tabel 1.


Tabel 1. Hasil uji beda rata- rata tinggi tanaman cabe rawit umur 14, 21 dan 28 HST terhadap pemberian beberapa dosis pupuk kandang kotoran ayam.

\begin{tabular}{cccc}
\hline Perlakuan & \multicolumn{3}{c}{ Rata-rata tinggi tanaman $(\mathrm{cm})$} \\
\cline { 2 - 4 } & $14 \mathrm{HST}$ & $21 \mathrm{HST}$ & $28 \mathrm{HST}$ \\
\hline $\mathrm{k}_{0}$ & $7,75^{\mathrm{a}}$ & $10^{\mathrm{a}}$ & $11,37^{\mathrm{a}}$ \\
$\mathrm{k}_{1}$ & $7,5^{\mathrm{a}}$ & $10,75^{\mathrm{a}}$ & $12,12^{\mathrm{a}}$ \\
$\mathrm{k}_{2}$ & $9,37^{\mathrm{ab}}$ & $16,5^{\mathrm{b}}$ & $18,5^{\mathrm{ab}}$ \\
$\mathrm{k}_{3}$ & $10 \mathrm{a}^{\mathrm{b}}$ & $19,75^{\mathrm{ab}}$ & $21,75^{\mathrm{ab}}$ \\
$\mathrm{k}_{4}$ & $9^{\mathrm{ab}}$ & $23,87^{\mathrm{ab}}$ & $26,12^{\mathrm{ab}}$ \\
$\mathrm{k}_{5}$ & $12,62^{\mathrm{b}}$ & $26,12^{\mathrm{b}}$ & $29,12^{\mathrm{b}}$ \\
$\mathrm{k}_{6}$ & $14^{\mathrm{b}}$ & $29,37^{\mathrm{b}}$ & $32,5^{\mathrm{b}}$ \\
\hline
\end{tabular}

Keterangan : Angka rata- rata yang diikuti oleh huruf yang sama pada kolom yang sama tidak berbeda nyata menurut DMRT pada taraf uji $5 \%$

Dari Tabel 1 diketahui bahwa rata-rata tinggi tanaman cabe rawit pada umur 14 HST perlakuan $\mathrm{k}_{0}$ (kontrol) adalah $7,75 \mathrm{~cm}$ yang tidak berbeda dengan perlakuan $\mathrm{k}_{1}(0,3 \mathrm{~kg}$ pupuk kandang kotoran ayam/lubang tanam) yaitu $7,5 \mathrm{~cm}$; perlakuan $\mathrm{k}_{2}(0,5 \mathrm{~kg}$ pupuk kandang kotoran ayam/lubang tanam) yaitu 9,37 cm; perlakuan $\mathrm{k}_{3}(0,9 \mathrm{~kg}$ pupuk kandang kotoran ayam/lubang tanam) yaitu $10 \mathrm{~cm}$; perlakuan $\mathrm{k}_{4}(1,1 \mathrm{~kg}$ pupuk kandang kotoran ayam/lubang tanam); berbeda dengan perlakuan $\mathrm{k}_{5}$ (1,4 kg pupuk kandang kotoran ayam/lubang tanam) yaitu $12,62 \mathrm{~cm}$ dan perlakuan $\mathrm{k}_{6}(1,7 \mathrm{~kg}$ pupuk kandang kotoran ayam/lubang tanam) yaitu $14 \mathrm{~cm}$. Perlakuan terbaik di peroleh pada perlakuan $\mathrm{k}_{5}(1,4 \mathrm{~kg}$ pupuk kandang kotoran ayam/lubang tanam). Sedangkan pada umur 21 HST rata-rata tinggi tanaman cabe keriting pada perlakuan $\mathrm{k}_{0}$ adalah $10 \mathrm{~cm}$ yang tidak berbeda dengan perlakuan $\mathrm{k}_{1}$ yaitu $10,75 \mathrm{~cm}$; perlakuan $\mathrm{k}_{2}$ yaitu $16,5 \mathrm{~cm}$; perlakuan $\mathrm{k}_{3}$ yaitu $19,75 \mathrm{~cm}$; perlakuan $\mathrm{k}_{4}$ yaitu $23,87 \mathrm{~cm}$; berbeda dengan perlakuan $\mathrm{k}_{5}$ yaitu $26,12 \mathrm{~cm}$ dan perlakuan $\mathrm{k}_{6}$ yaitu 29,37 cm. Perlakuan terbaik untuk tinggi tanaman $21 \mathrm{HST}$ adalah perlakuan $\mathrm{k}_{5}$ (1,4 kg pupuk kandang kotoran ayam/lubang tanam). Untuk rata-rata tinggi tanaman umur 35 HST perlakuan $\mathrm{k}_{0}$ adalah $11,37 \mathrm{~cm}$ yang tidak berbeda dengan perlakuan $\mathrm{k}_{1}$ yaitu $12,12 \mathrm{~cm}$; perlakuan $\mathrm{k}_{2}$ yaitu $18,5 \mathrm{~cm}$; perlakuan $\mathrm{k}_{3}$ yaitu $21,75 \mathrm{~cm}$; perlakuan $\mathrm{k}_{4}$ yaitu $26,12 \mathrm{~cm}$; berbeda dengan perlakuan $\mathrm{k}_{5}$ yaitu $29,12 \mathrm{~cm}$ dan perlakuan $\mathrm{k}_{6}$ yaitu 32,5 $\mathrm{cm}$. Perlakuan terbaik untuk tinggi tanaman 35 HST adalah perlakuan $\mathrm{k}_{5}$ (1,4 kg pupuk kandang kotoran ayam/lubang tanam).

\section{Umur Berbunga}

Berdasarkan hasil analisis ragam, pemberian beberapa dosis pupuk kandang kotoran ayam berpengaruh sangat nyata terhadap rata - rata umur berbunga tanaman cabe rawit. Hasil uji beda nilai tengah pemberian beberapa dosis pupuk kandang kotoran ayam terhadap rata - rata umur berbunga tanaman cabe rawit dapat dilihat pada Tabel 2.

Tabel 2. Hasil uji beda rata- rata umur berbunga tanaman cabe rawit terhadap pemberian beberapa dosis pupuk kandang kotoran ayam

\begin{tabular}{cc}
\hline Perlakuan & Rata-rata umur berbunga (HST) \\
\hline $\mathrm{k}_{0}$ & $53,75^{\mathrm{a}}$ \\
$\mathrm{k}_{1}$ & $52,75^{\mathrm{a}}$ \\
$\mathrm{k}_{2}$ & $51,75^{\mathrm{a}}$ \\
$\mathrm{k}_{3}$ & $48^{\mathrm{b}}$ \\
$\mathrm{k}_{4}$ & $44,5^{\mathrm{c}}$ \\
$\mathrm{k}_{5}$ & $41^{\mathrm{d}}$ \\
$\mathrm{k}_{6}$ & $40,5^{\mathrm{d}}$
\end{tabular}

Keterangan : Angka rata- rata yang diikuti oleh huruf yang sama pada kolom yang sama tidak berbeda nyata menurut DMRT pada taraf uji 5\% 
Fahrudin \& Mahdiannoor, Respon Pertumbuhan dan hasil tanaman...

Berdasarkan Tabel 2 dapat dilihat bahwa rata-rata umur berbunga terlama tanaman cabe rawit terdapat pada perlakuan $\mathrm{k}_{0}$ yaitu 53,75 hari yang tidak berbeda dengan perlakuan $\mathrm{k}_{1}$ yaitu 52,75 hari; perlakuan $\mathrm{k}_{2}$ yaitu 51,75 hari; berbeda dengan perlakuan $\mathrm{k}_{3}$ yaitu 48 hari; perlakuan $\mathrm{k}_{4}$ yaitu 44,5 hari; perlakuan $\mathrm{k}_{5} 41$ hari dan perlakuan $\mathrm{k}_{6}$ yaitu 40,5 hari. Perlakuan terbaik untuk umur berbunga adalah $\mathrm{k}_{5}$ (1,4 $\mathrm{kg}$ pupuk kandang kotoran ayam/lubang tanam tanam) yang tidak berbeda dengan perlakuan $\mathrm{k}_{6}$.

\section{Bobot Buah Segar Per tanaman}

Berdasarkan hasil analisis ragam, pemberian beberapa dosis pupuk kandang kotoran ayam berpengaruh sangat nyata terhadap rata - rata bobot buah segar per tanaman cabe rawit. Hasil uji beda nilai tengah pemberian beberapa dosis pupuk kandang kotoran ayam terhadap rata- rata bobot buah segar per tanaman cabe rawit dapat dilihat pada Tabel 3.

Tabel 3. Hasil uji beda rata- rata bobot buah segar per tanaman cabe rawit terhadap pemberian beberapa dosis pupuk kandang kotoran ayam.

\begin{tabular}{cc}
\hline Perlakuan & Rata-rata bobot buah segar per tanaman $(\mathrm{g})$ \\
\hline $\mathrm{k}_{0}$ & $79.16 \mathrm{~b}$ \\
$\mathrm{k}_{1}$ & $66.66 \mathrm{a}$ \\
$\mathrm{k}_{2}$ & $125 \mathrm{c}$ \\
$\mathrm{k}_{3}$ & $197.5 \mathrm{~d}$ \\
$\mathrm{k}_{4}$ & $329.16 \mathrm{e}$ \\
$\mathrm{k}_{5}$ & $383.33 \mathrm{f}$ \\
$\mathrm{k}_{6}$ & $79.16 \mathrm{~b}$
\end{tabular}

Keterangan : Angka rata- rata yang diikuti oleh huruf yang sama pada kolom yang sama tidak berbeda nyata menurut DMRT pada taraf uji 5\%

Berdasarkan Tabel 3 dapat dilihat bahwa rata-rata bobot buah segar per tanaman cabe rawit terdapat pada perlakuan $\mathrm{k}_{0}$ yaitu $79,16 \mathrm{~g}$ yang berbeda dengan perlakuan $\mathrm{k}_{1}$ yaitu $66,66 \mathrm{~g}$; perlakuan $\mathrm{k}_{2}$ yaitu $125 \mathrm{~g}$; perlakuan $\mathrm{k}_{3}$ yaitu 197,5 g; perlakuan $\mathrm{k}_{4}$ yaitu 329,16 g; perlakuan $\mathrm{k}_{5} 383,33 \mathrm{~g}$ dan tidak berbedanyata dengan perlakuan $\mathrm{k}_{6}$ yaitu 79,16 g. Perlakuan terbaik untuk bobot buah segar per tanaman adalah $\mathrm{k}_{4}(1,1 \mathrm{~kg}$ pupuk kandang kotoran ayam/lubang tanam) yaitu $329,16 \mathrm{~g}$ yang tidak berbeda dengan perlakuan $\mathrm{k}_{6}$.

\section{Pembahasan}

Berdasarkan hasil analisis ragam menunjukan bahwa pemberian perlakuan dosis pupuk kandang kotoran ayam berpengaruh nyata pada tinggi tanaman pada umur 14 HST, berpengaruh sangat nyata pada tinggi tanaman umur 21 dan 28 HST, hal ini karena ketersediaan unsur $\mathrm{N}$ yang cukup pada pupuk kotoran ayam masih mampu menunjang pada fase vegetatif tanaman cabe rawit khususnya pertumbuhan batang.

Menurut Hasibuan (2006), unsur hara $\mathrm{N}$ merupakan unsur hara makro utama yang dibutuhkan tanaman dalam jumlah yang banyak, dimana unsur $\mathrm{N}$ merupakan unsur bagi pertumbuhan tanaman yaitu merangsang pertumbuhan tanaman, berfungsi menyusun asam amino, protein dan protoplasma, selanjutnya akan berpengaruh terhadap pertumbuhan vegetatif tanaman.

Menurut Abdi (2010), esensialitas N terhadap pertumbuhan dan produksi tanaman terutama pada pertumbuhan vegetatif. Berperan dalam pembentukan protein dan asam nukleat inilah yang dipakai untuk pengisian inti sel yang terus membelah dari satu menjadi dua, dua menjadi empat, empat menjadi delapan dan seterusnya sehingga tanaman dapat tumbuh dan membesar.

Menurut Gardner et. al., (1991), defisiensi $\mathrm{N}$ membatasi pembesaran sel. Gejala defisiensi meliputi pertumbuhan umum yang kerdil dan lambat. Defisiensi K menyebabkan kerusakan kloroplas dan 
mitokondria sel tanaman, sehingga tanaman yang mengalami defisiensi $\mathrm{K}$ tidak mampu melakukan fotosintesis secara optimal, akibatnya tanaman tidak mampu menghasilkan fotosintat untuk mendukung pertumbuhan normal, kecuali itu fotosintat yang terbentuk menumpuk di daun akibat terganggunya transportasi asimilat.

Selain faktor unsur hara, faktor lingkungan juga sangat mempengaruhi pertumbuhan dan hasil tanaman cabe rawit faktor lingkungan tersebut yaitu cahaya, suhu, kelembaban tanah dan curah hujan. Pada waktu penelitian kondisi lingkungan kurang mendukung pertumbuhan dan hasil tanaman karena sering terjadi hujan sehingga berpengaruh terhadap tinggi rendahnya curah hujan dan mempengaruhi kadar air dalam tanah.

Pada saat penelitian dilaksanakan, hujan sering turun dan sering mendung karena bulan Juni tahun 2010 sudah terjadi musim penghujan. Hal tersebut mempengaruhi jumlah cahaya yang dapat di serap oleh tanaman sehingga berpengaruh pada proses fotosintesis.

Cahaya (yang umumnya diperoleh dari matahari) memiliki spektrum yang berbeda yang memiliki panjang gelombang yang beda. Cahaya berpengaruh terhadap pertumbuhan tanaman, karena merupakan bahan dari proses fotosintesis, bila tak ada cahaya, maka proses fotosintesis tak akan terjadi (Syaiful, 2009).

Pertumbuhan sangat dipengaruhi oleh suhu. Setiap jenis tumbuhan memiliki toleransi pada suhu minimum tertentu, suhu optimum tertentu, dan suhu maksimum tertentu. Toleransi ini berbeda-beda untuk tiap jenis tumbuhan. Pengaruh suhu dan cahaya matahari memberi pengaruh kompleks berkaitan dengan kedudukan tempat di bumi terhadap cahaya matahari (Syaiful, 2009).

Menurut Hanafiah (2005), suhu tanah adalah suatu sifat tanah yang sangat penting, secara langsung memengaruhi pertumbuhan tanaman, dimana suhu merupakan faktor tumbuhan tanaman yang sangat penting sebagaimana halnya air, udara dan unsur hara.
Selain faktor lingkungan tersebut, pada saat penelitian tidak ada hama dan penyakit yang menyerang sehingga tidak mempengaruhi pertumbuhan dan hasil tanaman cabe rawit.

\section{KESIMPULAN}

Pemberian beberapa dosis pupuk kandang kotoran ayam berpengaruh nyata terhadap tinggi tanaman umur 14 HST, dan berpengaruh sangat nyata terhadap tinggi tanaman umur 21 dan 28 HST, umur tanaman mulai berbunga dan berat basah tanaman cabe rawit. Perlakuan terbaik untuk pertumbuhan tinggi tanaman umur 14, 21 dan 28 HST; umur mulai berbunga dan bobot buah segar pertanaman cabe rawit adalah perlakuan $\mathrm{k}_{5}(1,4 \mathrm{~kg}$ pupuk kandang kotoran ayam/lubang tanam).

\section{DAFTAR PUSTAKA}

Abdi. 2010. Pentingnya Unsur Hara Bagi Tanaman. Http://www.tanindo.com Di akses tanggal 27 Juli 2010.

Dinas Pertanian Tanaman Pangan Propinsi

Kalimantan Selatan. 2006. Laporan

Tahunan Dinas Pertanian Tanaman

Pangan Tahun 2005. Banjarbaru.

Dinas Pertanian Tanaman Pangan Propinsi Kalimantan Selatan. 1996. Laporan Tahunan Dinas Pertanian Tanaman Pangan Tahun 1995. Banjarbaru.

Gardner, F.P., R. Brent Pearce dan Roger R. Mitchell. 1991. Fisiologi Tanaman Budidaya. Universitas Indonesia. Jakarta.

Hanafiah, K.A. 2005. Dasar-dasar Ilmu Tanah. PT. Raja Grafindo Persada. Jakarta.

Hasibuan. 2006. Unsur Hara Tanaman. Http://translate.google.co.id \& cangpair.com. Di akses tanggal 7 Agustus 2010. 
Fahrudin \& Mahdiannoor, Respon Pertumbuhan dan hasil tanaman...

Laboratorium Kimia, Fisika dan Biologi Tanah Faperta Unlam. 2010. Hasil Analisis Tanah. Banjarbaru

Munir, M. 1996. Tanah-tanah Utama Indonesia, Karakteristik, Klasifikasi, dan Manfaatnya. Pustaka Jaya, Jakarta.

Sunaryono, H. 2003. Budidaya Cabe Merah. Sinar Baru. Bandung.

Sutedjo, M.M., 1995. Pupuk dan Cara Pemupukan. Rineka Cipta. Jakarta.

Sutedjo, M.M. dan Kartasapoetra, 1991. Pengantar Ilmu Tanah. Rineka Cipta. Jakarta.

Syaiful. 2009. Unsur Hara Tanaman. Http://scrib.com. Di akses tanggal 27 Juli 2010. 